\title{
Mixed-valent Complexes of Rhodium with Acetylinic Ligands: Their Electrochemical Studies
}

\author{
Festus Agbo S. Fabiyi (Corresponding author) \\ Department of chemistry and Industrial Chemistry, Bowen University, Iwo, Nigeria \\ E-mail: sunfabiyi@yahoo.com \\ Carlos Stempler Gonzalez \\ INQUIMAE, Departamento de Quimica Inorganica, Analytica y Quimica Fisica \\ Facultad de Ciencias Exactas y Naturales, Universidad de Buenos Aires Pabellon II \\ Cuidad Universitaria, Nuñez (C1428 EHA), Capital Federal, Argentina \\ E-mail: gonscarlos@yahoo.com.ar \\ Gregory O. Adewuyi \\ Department of chemistry, Faculty of Science, University of Ibadan, Ibadan, Nigeria \\ E-mail: adewuyio@yahoo.com \\ Samuel Oluwole Aremu \\ Department of chemistry and Industrial Chemistry, Bowen University, Iwo, Nigeria \\ E-mail: wolearemu@yahoo.com
}

Received: February 9, 2011 Accepted: February 24, 2011 doi:10.5539/ijc.v3n3p62

\begin{abstract}
Two acetylinic mixed- valent rhodium(II, III) complexes: [cis- $\left.\left\{\mathrm{Rh}_{2}(\mathrm{II}, \mathrm{III}) \mathrm{Cl}(\mathrm{bpy})_{2}(\mu-\mathrm{C} \equiv \mathrm{C}-)\right\}\right]_{2}$, (A) and cis-[Rh(II,III)Cl(bpy) $]$-C $\equiv \mathrm{C}-\mathrm{SiMe}_{3}$, (B) (where bpy = bipyridine) have been prepared. (A) was accomplished through two pathways. The two complexes were characterized by ${ }^{1} \mathrm{H},{ }^{13} \mathrm{C} \mathrm{NMR}$, elemental, magnetic, electrochemical analyses and mass spectrophotometry. Cyclic voltametric analyses of the products from 0.00 $-1.20 \mathrm{~V}$ display two one-electron quasi-reversible oxidation peaks which were attributed to the $\mathrm{Rh}(\mathrm{II}), \mathrm{Rh}(\mathrm{III})$ couple. The redox processes were separated by $528 \mathrm{mV}$, indicating a significant electronic communication between the two metallic centres. The yields of (A) and (B) were found to be 37 and $32 \%$ respectively.
\end{abstract}

Keywords: Acetylinic, Mixed-valent rhodium, Electrochemical, Cyclic voltametric analyses

\section{Introduction}

Several researchers have extensively investigated organometallic polymers whose metal centres are joined by organic ligands with delocalized $\pi$-systems (Rusjan, et al., 2004; Kellogg, et al., 2005; Phimphaka, et al., 2010; Eweis, et al., 2006). Such species are of interest due to their potential usefulness in the areas of electronics and material science. From an inorganic chemistry point of view, the main interest is related to the multiple metal bonds and paramagnetic ground states that characterized the species (Zing, et al., 2008). Organometallic polymers, with transition metals linked by a polynediyl ligand, $M-(C \equiv C)_{n}-M$, have attracted increasing attention from various viewpoints (Serrano, et al., 1998; Estiu, et al., 1999; Fabiyi, et al., 2005).

The $\pi$-conjugated poly-carbon system is extended to the two terminal metal units.

Such systems are expected to display attractive properties resulting from $\pi$-conjugation along the rod-like linkage, stabilization of odd-electron (mixed-valent) species formed by hyper-polarizability, oxidation and reduction. Here we report the synthesis and characterization of complexes containing a bridging acetylinic ligand, 
synthesized from the reactions of $c i s-\left[\mathrm{RhCl}_{2}(\mathrm{bpy})_{2}\right] \cdot 2 \mathrm{H}_{2} \mathrm{O}$ with 1,4-bis(trimethylsilyl)-1,3-butadiyne or bis(trimethyl-silyl)acetylene and $\left[\mathrm{RhCl}_{2}(\mathrm{bpy})_{2}\right] \cdot 2 \mathrm{H}_{2} \mathrm{O}$ with bis(trimethylsilyl)acetylene. The complexes have been characterized by ${ }^{1} \mathrm{H},{ }^{13} \mathrm{C}$ NMR, MS and electrochemical analyses.

\section{Experimental}

Infrared spectra were recorded on a Beckman IR 4250 spectrophotometer. Samples were prepared as pressed pellets of $\mathrm{KBr} .{ }^{1} \mathrm{H}$ and ${ }^{13} \mathrm{C}$ spectra were obtained on a Bruker Model AC300/P spectrophotometer operating at 300 and $75.45 \mathrm{MHz}$, respectively, using tetramethylsilane as internal standard. Elemental analyses were performed on a Perkin-Elmer Model $2400 \mathrm{CHN}$ apparatus. Melting points (m. p.) were recorded on digital melting point apparatus WRS-IB and uncorrected. Mass spectra were measured with Finnigan trace DSQ spectrometer. Electrochemical measurements were performed on an EG\&G Princeton Applied Research (PAR) M273A electrochemical analyzer interfaced to an IBM computer employing PAR 270 electrochemical software. A standard three-electrode cell was designed to allow the tip of the reference electrode to closely approach the working electrode. All measurements were carried out under dry argon, in anhydrous deoxygenated acetonitrile; solution were $c a .1 \times 10^{-3} \mathrm{~mol} \cdot \mathrm{dm}^{-3}$ with respect to the compounds under study and $c a .0 .1 \mathrm{~mol} \cdot \mathrm{dm}^{-3}$ with respect to the supporting electrolyte, $\left[\mathrm{Bu}_{4} \mathrm{~N}\right]\left[\mathrm{ClO}_{4}\right]$.

A platinum disk working electrode, platinum wire auxiliary electrode and a saturated $\mathrm{Ag} / \mathrm{AgCl}$ reference electrode were used in these experiments.

All chemical used were analytical reagent grade purchased from Aldrich and were used without further purification. Rhodium trichloride hydrate, 1,8-diazabicyclo [5.4.0]undec-7-ene (DBU), 1,4-bis(trimethylsilyl) 1,3-butadiyne, bis(trimethylsilyl)acetylene, trimethylsilylacetylene and acetonitrile- $\mathrm{d}_{3}$ were used as received. Acetonitrile was treated with the appropriate drying agent, distilled and stored under argon. Other solvents were used without further purification. The complex, cis- $\left[\mathrm{RhCl}_{2}(\mathrm{bpy})_{2}\right] \cdot 2 \mathrm{H}_{2} \mathrm{O}$ was prepared according to the published method (Abied, et al., 1978).

\subsection{Preparation of Complexes: Synthesis of cis- $\left[R h_{2}(I I, I I I) C l(b p y)_{2}(-\mu-C \equiv C-)\right]_{2},(\mathbf{A})$}

$50.00 \mathrm{~mL}$ of a mixture $(8: 1)$ of $\mathrm{MeOH} / \mathrm{CH}_{2} \mathrm{Cl}_{2}, 8.00 \mathrm{~mL}$ of $0.33 \mathrm{mmol}$ of $\mathrm{NaBF}_{4}, 5 \mathrm{~mL}$ of $0.6 \mathrm{mmol}$ of NaF were all added to $0.35 \mathrm{~g}$ of cis-[ $\left[\mathrm{RhCl}_{2}(\mathrm{bpy})_{2}\right] \cdot 2 \mathrm{H}_{2} \mathrm{O}$ in a conical flask. The content of the flask were emptied into another flask containing $15 \mathrm{~mL}$ of $0.18 \mathrm{mmol}$ suspension of 1,4-bis(trimethyl)1,3-butadiyne (pathway A) or $10.00 \mathrm{ml}$ of $0.20 \mathrm{mmol}$ of bis(trimethylsilyl)acetylene (pathway B). The mixture was then thoroughly mixed and refluxed for about $48 \mathrm{hrs}$ at a constant temperature of of $62{ }^{\circ} \mathrm{C}$ on a heater fitted with magnetic stirrer. The solution was allowed to cool to room temperature (about $295^{\circ} \mathrm{K}$ ) and then filtered on a 4 fritte grade filter paper. The filtrate was allowed to evaporate under vacuum to about $1 / 4$ of the original volume in order to remove the solvent. The complex precipitated on the addition of about $6 \mathrm{~mL}$ diethyl ether. The precipitate was dissolved in $\mathrm{CH}_{2} \mathrm{Cl}_{2}$ and $\mathrm{passed}$ through an alumina plug to remove salts. Black crystals of the complex, $(\mathbf{A})$ were obtained on addition of $n$-hexane. The crystals were then washed and re-crystallized from methanol, dried in desiccators over $\mathrm{CaCl}_{2}$, then, in vacuum.

\subsection{Synthesis of cis-[Rh $\left.{ }_{2} \mathrm{Cl}(\text { bpy })_{2}\right]-C \equiv C-S i M e, \mathbf{B}$}

$25 \mathrm{~mL}$ of $90 \%$ degassed acetone, $5 \mathrm{~mL}$ of $0.43 \mathrm{mmol}$ of $\mathrm{AgBF}_{4}$ and $5 \mathrm{~mL}$ of 0.40 mmol of solution of cis- $\left[\mathrm{RhCl}_{2}(\mathrm{bpy})_{2}\right] \cdot 2 \mathrm{H}_{2} \mathrm{O}$ were mixed together in a flask and stirred magnetically for about $6 \mathrm{~h}$ under argon. The reaction mixture was then filtered through a 4 fritte grade filter paper and degassed by bleeding argon through the solution for $30 \mathrm{mins}$. Then $5 \mathrm{~mL}$ of $0.45 \mathrm{mmol}$ of $\mathrm{H}-\mathrm{C} \equiv \mathrm{C}-\mathrm{SiMe}_{3}$ was added and the reaction mixture was heated at a constant temperature of $338^{\circ} \mathrm{K}$ on a heater supplied with magnetic stirrer for $48 \mathrm{~h}$. The resulting solution was filtered and the solvent removed by rotatory evaporator to a quarter of the original volume and precipitated with addition of diethylether. The crystals obtained were dissolved in $\mathrm{CH}_{2} \mathrm{Cl}_{2}$ and passed through an alumina to remove salts. The complex $\mathbf{B}$ was precipitated on addition of hexane. It was re-crystallized as in the case of $\mathbf{A}$.

\section{Results and Discussion}

The yields, elemental analyses, molar conductivities and other parameters of the complexes are shown in Table 1.The proposed synthetic route of $\mathbf{A}$ is shown in equations (1-4). The 1, 4-butadiyne bridging ligand is generated in situ by the fluoride-induced ${ }^{6}$ cleavage of the terminal trimethylsilyl groups (equation 1 ).

$$
\begin{gathered}
\mathrm{Me}_{3} \mathrm{Si}-\mathrm{C}-\mathrm{C} \equiv \mathrm{C}-\mathrm{C} \equiv \mathrm{C}-\mathrm{SiMe}_{3}+2 \mathrm{NaF} \rightarrow \mathrm{H}-\mathrm{C} \equiv \mathrm{C}-\mathrm{C} \equiv \mathrm{C}+2 \mathrm{Me}_{3} \mathrm{SiF}+2 \mathrm{MeONa} \\
2 \text { cis- }\left[\mathrm{RhCl}_{2} \text { (bpy) }_{2}\right]+2 \mathrm{NaBF}_{4} \rightarrow 2 \text { cis- }\left[\mathrm{RhCl}(\text { bpy })_{2}\right]\left[\mathrm{BF}_{4}\right]+2 \mathrm{NaCl}
\end{gathered}
$$


As described, ${ }^{7,8}$ the $\mathrm{BF}_{4}{ }^{-}$anion acts as a halide abstractor (equation 2) to promote the complexation of the terminal alkyne at the rhodium center, giving the vinylidene complex isolated in many cases as the final product of the reaction (eq. 3).

$$
\text { 2cis- } \left.\left[\mathrm{RhCl}_{2}(\text { bpy })_{2}\right]\left[\mathrm{BF}_{4}\right]+\mathrm{H}-\mathrm{C} \equiv \mathrm{C}-\mathrm{C} \equiv \mathrm{C}-\mathrm{H} \rightarrow \text { cis- }\left[\mathrm{RhCl}(\text { bpy })_{2}\right)_{2}\left(=\mathrm{C}=\mathrm{C}=\mathrm{C}=\mathrm{C}-\mathrm{H}_{2}\right)\right]\left[\mathrm{BF}_{4}\right]_{2}
$$

However, under these conditions, the cleavage of the trimethylsilyl group is associated with the formation of a stoichiometric amount of a strong base. This base in situ deprotonates the vinylidene intermediate, allowed the formation of the bis-(rhodium alkynyl) complex 1 as the final product of the reaction (eq. 4).

$$
\left.\left.\left.\operatorname{cis}\left[\mathrm{RhCl}(\mathrm{bpy})_{2}\right)_{2}\left(\mathrm{C}=\mathrm{C}=\mathrm{C}=\mathrm{C}-\mathrm{H}_{2}\right)\right][\mathrm{BF} 4]_{2}+2 \mathrm{MeONa}-----[\mathrm{cis}-\} \mathrm{RhCl}(\mathrm{bpy}) 2(\mu--\mathrm{C} \equiv \mathrm{C}-)\right\}\right]_{2}+2 \mathrm{MeOH}+2 \mathrm{NaBF}_{4}
$$

This is the first example reported so far of a di-ynediyl complex bearing the $\mathrm{RhCl}(\mathrm{bpy})_{2}$ fragment. Because of the complexity of the ${ }^{1} \mathrm{H}$ and ${ }^{13} \mathrm{C}$ spectra it is not possible to use it to characterize the complex. The absence of the absorption of the $-\mathrm{C} \equiv \mathrm{C}$ - stretching in the IR spectrum and the presence of the two quasi-reversible oxidation peaks in the cyclic voltammogram revealed by the electrochemical studies, attributed to the couple $\mathrm{Rh}(\mathrm{II}) / \mathrm{Rh}$ (III, suggest that compound $\mathbf{A}$ is a dimmer. Attempts to obtain $\left[\right.$ cis- $\left.\left\{\mathrm{Rh}_{2} \mathrm{Cl}(\mathrm{bpy})_{2}\right\}_{2}(-\mathrm{C} \equiv \mathrm{C}-)\right]$ by reacting cis-[ $\left[\mathrm{RhCl}_{2}(\mathrm{bpy})_{2}\right] 2 \mathrm{H}_{2} \mathrm{O}$ with bis(trimethylsilyl) acetylene under the same conditions used for the reaction with 1,4-bis(trimethylsilyl)-1,3-butadiyne, surprisingly, afforded the same complex $\mathbf{A}$ whose elemental analyses, ${ }^{1} \mathrm{H}$ NMR and ${ }^{13} \mathrm{C}$ NMR data are very close to that of complex synthesized using 1,4-bis(trimethylsilyl)-1,3-butadiyne as the ligand. Dimerization of the bis(trimethylsilyl)acetylene ligand probably occurred due to the temperature used, considering that the dimerization of the bis(trimethylsilyl) acetylene ligand does not occur at room temperature. All attempts to obtain complex $\left[\operatorname{cis}\left\{\mathrm{Rh}_{2} \mathrm{Cl}(\mathrm{bpy})_{2}\right\}_{2}(-\mathrm{C} \equiv \mathrm{C}-)\right]$ using other methods were unsuccessful.

Complex $\mathbf{B}$ was prepared by reaction of the free ligand, $\mathrm{H}-\mathrm{C} \equiv \mathrm{C}-\mathrm{SiMe}_{3}$ with cis- $\left[\mathrm{RhCl}(\mathrm{bpy})_{2}\left(\mathrm{CH}_{3} \mathrm{COCH}_{3}\right)\right]^{+}(\mathrm{eq} 5,6)$

$$
\begin{gathered}
\text { Cis- } \left.\left[\mathrm{RhCl}_{2}(\text { bpy })_{2}\right]+\mathrm{AgBF}_{4}{ }^{\text {acetone }} \rightarrow \text { cis- }\left[\mathrm{RhCl}(\text { bpy })_{2} \text { (acetone }\right)\right]^{+}+\mathrm{BF}_{4}^{-}+\mathrm{AgCl} \\
\left.\left.\mathrm{Cis}-\left[\mathrm{RhCl}(\mathrm{bpy})_{2}\left(\mathrm{CH}_{3} \mathrm{COCH}_{3}\right)\right]^{+}+\mathrm{H}-\mathrm{C} \equiv \mathrm{C} \mathrm{SiMe} 3\right)\right]^{\mathrm{DBU}} \rightarrow \mathrm{cis}\left[\mathrm{RhCl}\left(\mathrm{bpy}_{2}\right)\left(\mathrm{C} \equiv \mathrm{C}-\mathrm{SiMe}_{3}\right)\right]+\mathrm{CH}_{3} \mathrm{COCH}_{3}
\end{gathered}
$$

The monoacetone complex is known to be a valuable synthetic intermediate (Tian, et al., 2005). The preparation of the monoacetone complex must be carefully timed (Banford, et al., 2002; Heinrich, et al., 2002; Fabiyi, et al., 2005). After short reaction times $(<2 \mathrm{~h})$, the complex is not completely formed, the limiting factor being the rate of dissolution of cis- $\left[\mathrm{RhCl}_{2}(\mathrm{bpy})_{2}\right] \cdot 2 \mathrm{H}_{2} \mathrm{O}$ in acetone. After long reaction times $(>2 \mathrm{~h})$, a dark, red-brown precipitate begins to form. Isolation of this complex showed it to be identical with dimer cis- $\left[\mathrm{RhCl}(\mathrm{bpy})_{2}\right]_{2}\left[\mathrm{BF}_{4}\right]_{2}$ as revealed by cyclic voltametry. Isolation of complex $\mathbf{B}$ was achieved by precipitation from an acetone solution by adding diethyl ether, after filtration through an alumina plug to remove salts.

The characteristic IR bands of the complexes are listed in Table 2. The assignments of the spectra bands have been carried out with references to related studies (Banford, et al., 2002; Kahn, et al., 1975).

The ${ }^{1} \mathrm{H}$ NMR spectrum of $\left[\mathrm{Rh}_{2} \mathrm{Cl}_{2}(\text { bipy })_{2}\right]$, in $\left(\mathrm{DMSO}^{\left.-\mathrm{d}_{6}\right)}\right.$ has been discussed in the literature and shown to be more complex than expected for the cis or trans configurations (Kellogg, et al., 2005; Heinrich, et al., 2002). The reason for the complexity of the spectrum is that a mixture of cis and trans compounds were present in solution, with possible solvent interaction (Fabiyi, et al., 2005; Hench, et al., 1984). In the cis configuration, the molecule has no symmetry so that the 16 bipyridine hydrogens are expected to be unique. A first-order coupling scheme predicts eight doublets and eight triplets for the ${ }^{1} \mathrm{H}$ NMR spectrum assigned to the aromatic hydrogens of bipyridine. In fact, complexes $\mathbf{A}$ and $\mathbf{B}$ showed a more complicated pattern of ${ }^{1} \mathrm{H}$ and ${ }^{13} \mathrm{CNMR}$ spectra in the aromatic region, which would be expected for a cis or trans compounds.

The ${ }^{13} \mathrm{C}$ NMR spectra of the complexes studied are similar in the aromatic region and display five sets of resonances, concentrated at $\delta$ : 160.4-158.6, 154.3-149.5, 139.0-136.9, 127.2-126.7 and 123.7-122.7. Each set of resonance exhibits more peaks than would be expected for the cis configuration. This is in agreement with the fact that the pyridine groups of each ligand are not magnetically equivalent and both cis and trans configurations probably would be present. Moreover, in these complexes, the ${ }^{13} \mathrm{C}$ NMR signals of the Rh-C $\equiv \mathrm{C}$ - carbons are masked by the signals of pyridyl carbons. The mass spectrum for A shows sets of peaks at $\mathrm{m} / z$ 102, 921, 993, 1017.5 and the maximum 1053.5. There are many peaks just below the expected masses of the parent ion, $\mathrm{m} / \mathrm{z}=$ 1053.5. The presence of lower-mass peaks suggests that fragmentation occurred. They are dominated by single intense peaks but accompanied by a number of weaker ones. The separation between each set can be explained as follows: 1053.5-1017.5 = 35.5, 1053.5-921, 1053-993, 1053.5-983 and 1053.5-206 are attributed to losses of $\mathrm{Cl}^{-}$, 2 bipyrimidyl ions, acetylinic ligand and $2 \mathrm{Rh}$ ions respectively. For compound $\mathbf{B}$ the following $\mathrm{m} / \mathrm{z}$ were observed: $567,552,537,501.5,470$, and 273, 206, and 103. These correspond to losses of $\mathrm{Me}, 2 \mathrm{Me},-\mathrm{C} \equiv \mathrm{C}-\mathrm{SiMe}, \mathrm{Cl}^{-}, 2$ bipyridyl, $2 \mathrm{Rh}$, and one $\mathrm{Rh}$ ions respectively. 
Cyclic voltammetric analysis of $\left[\text { cis- }\left\{\mathrm{RhCl}(\text { bpy })_{2}(-\mathrm{C} \equiv \mathrm{C}-)\right)_{2}\right]_{2}$ and cis- $\left[\mathrm{RhCl}(\mathrm{bpy})_{2}\right]-\mathrm{C} \equiv \mathrm{C}-\mathrm{SiMe}_{3}$.

The results of cyclic voltammetry experiments in $\mathrm{CH}_{3} \mathrm{CN}$ solution for the compounds $\mathbf{A}$ and $\mathbf{B}$ and the starting complex cis- $\left[\mathrm{Ru}_{2} \mathrm{Cl}_{2}\left(\mathrm{bpy}_{2}\right]\right.$ are given in Table 3. The results of the cyclic voltammetric experiments on cis- $\left[\mathrm{Rh}_{2} \mathrm{Cl}_{2}(\mathrm{bpy})_{2}\right]$ in $\mathrm{CH}_{3} \mathrm{CN}$ at room temperature are shown in Figure 1. This compound exhibited two quasi-reversible oxidation peaks at $\mathrm{E}_{1 / 2}+2.07$ and $+0.410 \mathrm{~V} \mathrm{vs} \mathrm{Ag} / \mathrm{AgCl}$ and two quasi-reversible reduction peaks at $\mathrm{E}_{1 / 2}-1.48$ and $-1.61 \mathrm{~V}$ vs Ag/AgCl. The peaks at +2.07 and $+0.410 \mathrm{~V}$ were attributed to the $\mathrm{Rh}(\mathrm{III}) / \mathrm{Rh}(\mathrm{IV})$ and $\mathrm{Rh}(\mathrm{II}) / \mathrm{Rh}(\mathrm{III})$ couples, respectively. The two reduction peaks at -1.48 and $-1.61 \mathrm{~V}$ were ascribed to the bpy ligand. These results are consistent with the previous study on similar complex (Rusjan, et al., 2005; Kahn, et al., 1975; Carraher, et al., 1985). The same electrochemical behavior was shown by compound B (see Figure 2). This compound shows two quasi-reversible oxidation peaks at $\mathrm{E}_{1 / 2}+1.53$ and $+0.410 \mathrm{~V}$ vs $\mathrm{Ag} / \mathrm{AgCl}$, owing to the $\mathrm{Rh}(\mathrm{III}) / \mathrm{Rh}(\mathrm{IV})$ and $\mathrm{Rh}(\mathrm{II}) / \mathrm{Rh}(\mathrm{III})$ couples, respectively, and a irreversible reduction process at $-1.25 \mathrm{~V}$ and two quasi-reversible peaks at -1.39 and $-1.56 \mathrm{~V}$ vs $\mathrm{Ag} / \mathrm{AgCl}$, due to the bpy ligand. Table 3 shows that the potential of the $\mathrm{Rh}(\mathrm{II}) / \mathrm{Rh}$ (III) couple in complex cis-[ $\left.\mathrm{RhCl}_{2}(\mathrm{bpy})_{2}\right]$ and $\mathbf{B}$ is the same as in compound $\mathbf{A}$, which implies that the $\mathrm{Rh}$ (II) orbital energy is unchanged in the complex $\mathbf{B}$ when of the substitution of the trimethyl(silyl) acetylide by one chloride on cis- $\left[\mathrm{RhCl}_{2}(\mathrm{bpy})_{2}\right]$ complex. The cyclic voltammetric response for dimeric complex (A) is shown in Figure 3. This complex displays one irreversible oxidation peak at $+2.05 \mathrm{~V}$ vs $\mathrm{Ag} / \mathrm{AgCl}$, ascribed to the $\mathrm{Rh}(\mathrm{III}) / \mathrm{Rh}(\mathrm{IV})$ couple and two quasi-reversible reduction peaks at -1.42 and $-1.61 \mathrm{~V}$ vs $\mathrm{Ag} / \mathrm{AgCl}$, due to the reduction of the bpy ligand. Two oxidation peaks at +0.351 and $+0.871 \mathrm{~V}$ vs $\mathrm{Ag} / \mathrm{AgCl}$ with the $\mathrm{i}_{\mathrm{pc}} / \mathrm{i}_{\mathrm{pa}}$ current ratio of unity were attributed to the $\mathrm{Rh}(\mathrm{II}) / \mathrm{Rh}(\mathrm{III})$ couple.

This means that the neutral dimer undergoes two successive one-electron oxidations to yield the mono- and the di-cations, respectively (eq 7).

$$
\mathrm{Ru}(\mathrm{II})-\mathrm{Ru}(\mathrm{II})^{-\mathrm{e}} \leftrightarrow\left[\mathrm{Ru}(\mathrm{II})-\mathrm{Rh}(\mathrm{III})^{+-\mathrm{e}} \leftrightarrow\left[\mathrm{Rh}(\mathrm{III})-\mathrm{Rh}(\mathrm{III})_{2}\right.\right.
$$

The $\Delta \mathrm{E}_{\mathrm{p}}$ value for the two redox processes is $528 \mathrm{mV}$, clearly indicates a strong communication between the two rhodium centers propagated throughout the orbitals of the $-\mathrm{C} \equiv \mathrm{C}-\mathrm{C} \equiv \mathrm{C}$ - bridge. This reflects the extent of the delocalization between metal centers in the ground state. The important stabilization of the mixed-valence $\mathrm{Rh}(\mathrm{II}) / \mathrm{Rh}(\mathrm{III})$ state is shown by the large value of the comproportionation constant, $\mathrm{K}_{\mathrm{C}}=6.13 \times 10^{8}$. The one-dimensional $-\mathrm{C}_{4}$ - bridge acts as a molecular wire to convey the odd electron from one metal center to the other. Figure 4 shows the cyclic voltammetric response for complex A, synthesized using bis(trimethylsilyl) acetylene as the ligand. The one irreversible oxidation peak observed at $+2.02 \mathrm{~V} \mathrm{vs} \mathrm{Ag} / \mathrm{AgCl}$ was ascribed to the $\mathrm{Rh}(\mathrm{III}) / \mathrm{Rh}(\mathrm{IV})$ couple, the two quasi-reversible peaks at -1.42 and $-1.62 \mathrm{~V} \mathrm{vs} \mathrm{Ag/AgCl}$ were assigned to the reduction of the bpy ligand and the two reversible peaks $\left(\mathrm{i}_{\mathrm{pc}} / \mathrm{i}_{\mathrm{pa}}=1\right)$ at +0.354 and $+0.874 \mathrm{~V}$ vs $\mathrm{Ag} / \mathrm{AgCl}$ were ascribed to the dimer $\mathrm{Rh}(\mathrm{II}) / \mathrm{Rh}(\mathrm{III})$ couple that undergoes two successive one-electron oxidations $\left(\mathrm{DE}_{\mathrm{p}}=520 \mathrm{mV}\right)$ to yield the monoand the di-cations, respectively.

The data on Table III and the electrochemical behavior presented in Figures 3 and 4 for compound A obtained from 1,4-bis(trimethylsilyl)1,3-butadiyne or bis(trimethylsilyl) acetylene are very similar. We therefore, suggest that these compounds are the same. As stated above, dimerization of the ligand may occur, owing of the mechanism of the reaction and the temperature used, since the reaction does not occur at room temperature. Moreover, it was expected that the communication between the two metallic centers of dimer complexes having a bridged acetylenic linkage would be greater than that between metallic centers linked by a bridging butadiyne. Since $\Delta \mathrm{E}_{\mathrm{p}}$ values for the two compounds reported herein are the same, $520 \mathrm{mV}$, these compounds should be the same.

Hence two new complexes of rhodium with bridging acetylinic ligands have been successfully prepared and characterized. Possibilities of their mesomorphic properties are being studied.

\section{Acknowledgements}

The financial support for this work by the Third World Academy of Science (TWAS), Trieste, Italy, through an award of fellowship to FAS is gratefully acknowledged.

\section{References}

Abied, H., Guillon, D. \& Marchon, J. C. (1978). Polyalkylrhodiumtrihalides: synthesis, mechanistic and spectroscopic aspects. J. organomet.chem, 156(3), 230-234.

Banford, C.H. \& Tipper C. F. H. (2002). Chemical kinetics reactions of rhodium complexes. Solid state, 48, 65-69.

Carraher, J.E. \& Pittman, C. E. (1985). Metal-containing polymeric systems $\left(3^{\text {rd }}\right.$ ed), New York, Wiley. 
Estiu, G., Cukiernik, F. D. \& Maldivi, P. (1999). Electronic, magnetic and spectroscopic properties of binuclear dirhodium tetracaboxylates: A theoretical and experimental study. Inorg. Chem., 38, 3030-3039.

Eweis, M. \& Elsabec M. Z. (2006). Evaluations of novel carbonyls with acetylene derivatives. Int. J. of Bio. Micromol., 38, 1-6.

Fabiyi, F. A.S., Cukiernik, F. D. \& Olatunji, M.A. (2005). Effect of introducing dicarboxyl linkages on the molecular organization of dirhodium (II) long-chain carboxylates: synthesis, characterization and mesomorphic properties. Can. J. Chem., 84, 623-630.

Heinrich, B., Donnio, B. \& Rusjan, M. (2002). Lyotropic behaviour of dirhodium (II,III) alkybenzoates in dodecane. Langmuir, 18, 10116-10119.

Hench, L.L. \& Ulrich, D.R. (1984). Ultrastructure processing of ceramics, glasses and composites, $2^{\text {nd }}$ ed., New York, Wiley.

Kahn, O. \& Biat, J. B. (1975). Elecrochemical analysis and structural correlations in exchange coupled systems. $J$. Am. Chem. Soc., 97, 4884.

Kellogg, G. E. \& Gaugiello, J. G. (1992). Metal complexes of acetylinic ligands.In Inorganic materials. New York, John Wiley and Sons, 353-357.

Phimphaka, H., David, J. H. \& Harry, A. (2010). Synthesis and electrochemical studies of nickel $\beta$-diketone complexes incorporating asymmetric dimeric ligands. Aus. Jour. Of Chem., 63(1), 75-82.

Rusjan, M., Donnio,B., Guillon, D. \& Cukiernik, F. D. (2002). Liquid-crystalline materials based on rhodium carboxylate coordination polymers: synthesis, characterization and mesomorphic properties of tetra(alkoxybenzoato)dirhodium(II) complexes and their pyrazine adducts. Chem.Mater., 14, 1564-1575.

Rusjan, M.; Sileo, E. E. \& Cukiernik, F. D. (2005). Thermal stability of mixed-valent diruthenium(II,III) carboxylates. Solid state inonics, 159, 389-396.

Serrano, J.L. ed. Metallomesogens. (1996). Germany, VCH: Weinheim, 243.

Tian, L. Zhou, Z. \& Zhang, C. (1986). Synthesis and characterization of $\beta$-alkoxycarboxylethylrhodiumchloride. Polyhedron, 5(3), 842-845.

Zhong, Z.; Xing, R. \& Li, P. (2008). Synthesis of the acyl thiourea derivatives of some transition metals. Carbohydrates Res., 343, 566-570.

Table 1. Physical properties and elemental analyses of complexes

\begin{tabular}{|c|c|c|c|c|c|c|c|c|}
\hline & \multicolumn{8}{|c|}{ Analysis \% Found (Calculated) } \\
\hline $\begin{array}{l}\text { Empirical Formula } \\
\text { (Formula Weight) }\end{array}$ & Colour & $\begin{array}{l}\text { Yield } \\
(\%)\end{array}$ & M.Pt $\left({ }^{\circ} \mathrm{C}\right)$ & $\mathrm{N}$ & $\mathrm{C}$ & $\mathrm{H}$ & $\begin{array}{c}\mu \text { eff } \\
\text { (B.M.) }\end{array}$ & $\begin{array}{c}\Lambda \max \\
\left(\Omega^{-1} \mathrm{~cm} \mathrm{Mol}^{2}\right)\end{array}$ \\
\hline $\begin{array}{c}\mathrm{C}_{34} \mathrm{H}_{33} \mathrm{~N}_{4} \mathrm{Cl}_{2} \mathrm{Rh}_{2} \\
(1053.04)\end{array}$ & black & 37.33 & $267-9$ & $11.87(11.91)$ & $55.87(55.86)$ & $3.34(3.36)$ & 4.4 & 7.4 \\
\hline $\begin{array}{c}\mathrm{C}_{16} \mathrm{H}_{22} \mathrm{~N}_{4} \mathrm{Rh}_{2} \mathrm{ClSi} \\
(567)\end{array}$ & black & 32.65 & $259-61$ & $10.36(10.26)$ & $54.58(54.55)$ & $4.59(4.61)$ & 3.66 .3 & 7.4 \\
\hline
\end{tabular}


Table 2. Selected infrared bands $\left(\mathrm{cm}^{-1}\right)$ of the complexes ${ }^{b}$

\begin{tabular}{|c|c|c|c|c|c|c|c|c|}
\hline Compound & $v(\mathrm{C}=\mathrm{C})$ & $v \mathrm{C}=\mathrm{Ar})$ & $v(\mathrm{Rh}-\mathrm{C})$ & $v(\mathrm{C}=\mathrm{N})$ & $v(\mathrm{C}-\mathrm{N})$ & $v(\mathrm{Rh}-\mathrm{N})$ & $v(\mathrm{Si}-\mathrm{C})$ & $v(\mathrm{C}-\mathrm{H})$ \\
\hline $\mathrm{C}_{34} \mathrm{H}_{33} \mathrm{~N}_{4} \mathrm{Cl}_{2} \mathrm{Rh}_{2}$ & $3117 \mathrm{~m}$ & $1596 \mathrm{~m}$ & $726 \mathrm{~s}$ & $1634 \mathrm{~m}$ & $1675 \mathrm{~s}$ & $676 \mathrm{~s}$ & - & $2955 \mathrm{~m}$ \\
\hline $\mathrm{C}_{16} \mathrm{H}_{22} \mathrm{~N}_{4} \mathrm{Rh}_{2} \mathrm{ClSi}$ & $1973 \mathrm{~m}$ & $3115 \mathrm{~s}$ & $728 \mathrm{~s}$ & $1629 \mathrm{~s}$ & $1673 \mathrm{~m}$ & $674 \mathrm{~s}$ & $701 \mathrm{~m}$ & $2952 \mathrm{~s}$ \\
\hline
\end{tabular}

$\mathrm{b}_{\mathrm{s}}=$ strong, $\mathrm{m}=$ medium, $\mathrm{s}=$ sharp, br $=$ broad.

Table 3. Cyclic voltammetry results for complexes (A) and (B) and $\mathrm{RhCl}_{2}(\mathrm{bpy})_{2}$

\begin{tabular}{|c|c|c|}
\hline Complex & ${ }^{\mathrm{a}} \mathrm{E}^{1} / 2(\mathrm{~V})$ & ${ }^{\mathrm{b}} \mathrm{Kc}$ \\
\hline \multirow{2}{*}{$A^{c}$} & $+2.47^{\mathrm{e}},+2.05^{\mathrm{e}}, 0.870$ & \multirow{2}{*}{$6.14 \times 10^{8}$} \\
\hline & $+0.349,-1.40,-1.63$ & \\
\hline \multirow{2}{*}{$A^{d}$} & $+2.45^{\mathrm{e}},+2.02^{\mathrm{e}},+0.874$ & \multirow{2}{*}{$6.14 \times 10^{8}$} \\
\hline & $0.350,-1.41,-1.62$ & \\
\hline \multirow{2}{*}{ B } & $+1.53,+0.412,-1.24^{\mathrm{e}}$ & \\
\hline & $-1.39, \quad-1.56$ & \\
\hline \multirow{2}{*}[\mathrm{RhCl}_{2}(\mathrm{bpy})_{2}]{} & $+2.06^{\mathrm{e}},+0.411$ & \\
\hline & $-1.48,-1.63$ & \\
\hline
\end{tabular}

${ }^{\mathrm{a}}$ In $\mathrm{CH}_{3} \mathrm{CN}$ solution at $293{ }^{\circ} \mathrm{K}, 200 \mathrm{mV}^{5-1}$. E⿺辶2 values were obtained from the average of the anodic and cathodic peak potentials ${ }^{b} \mathrm{~L}_{\mathrm{n}} \mathrm{Kc}=\left(\mathrm{n}_{1} \mathrm{E}_{1}{ }^{\theta}-\mathrm{n}_{2} \mathrm{E}_{2}{ }^{\theta}\right) \mathrm{F} / \mathrm{RT}$ with $\mathrm{n}_{1}=\mathrm{n}_{2}=1$.

${ }^{\mathrm{c}}$ synthesized complex from pathway A. ${ }^{\mathrm{d}}$ synthesized complex from pathway B and irreversible peaks.

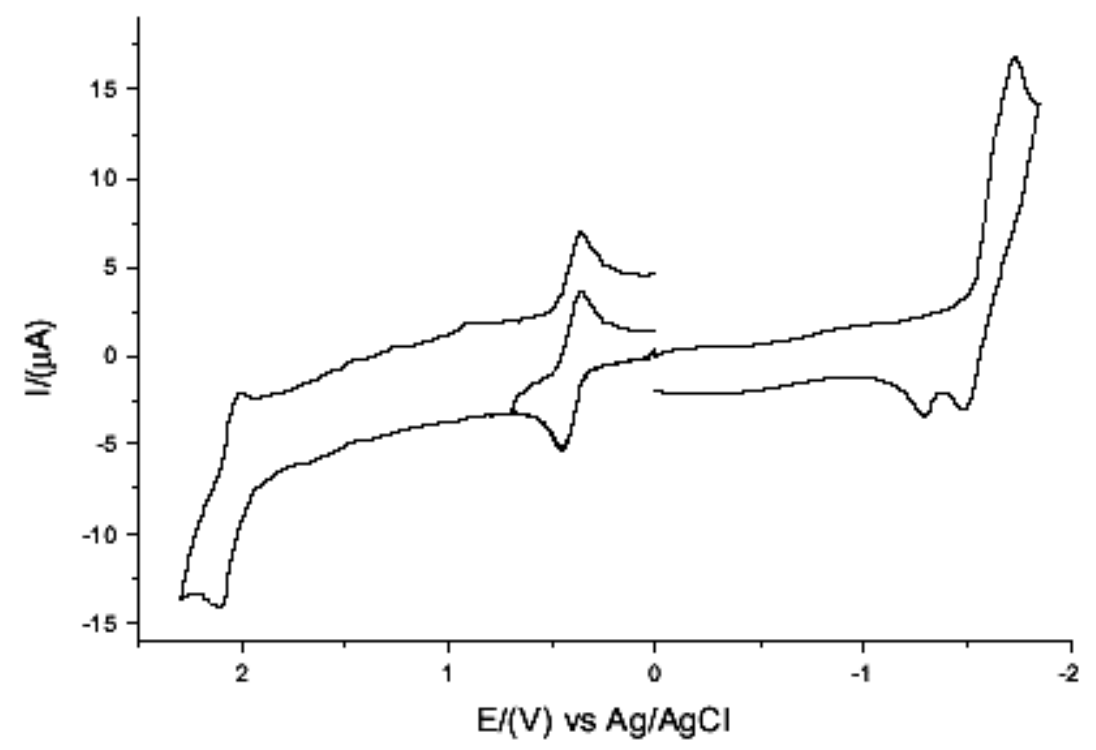

Figure 1. Cyclic voltammetric response for complex $\mathbf{A}$ at $200 \mathrm{mV} \mathrm{s}^{-1}$, at room temperature (two scans) 


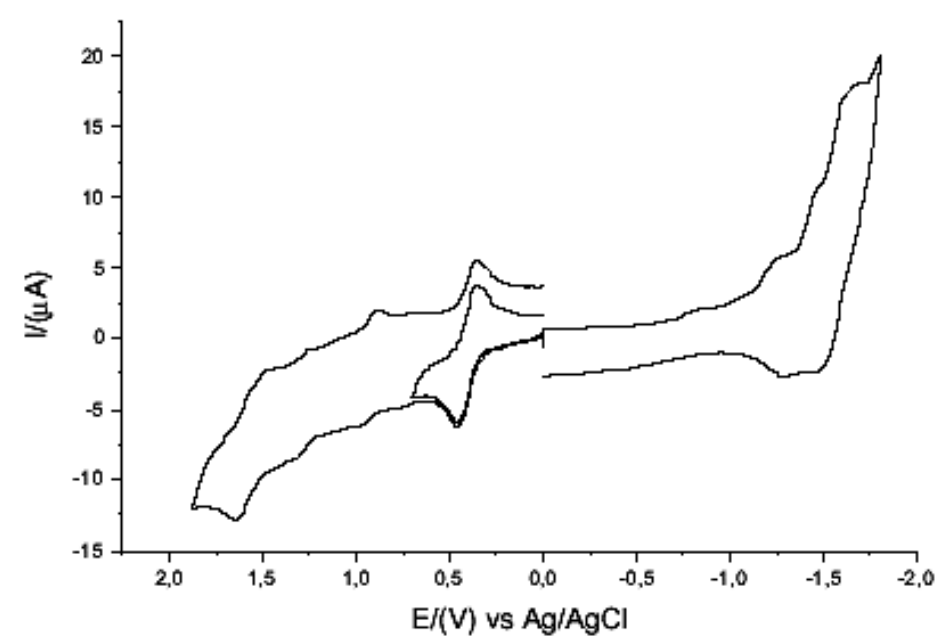

Figure 2. Cyclic voltammetric response for complex $\mathbf{B}$ at $200 \mathrm{mV} \mathrm{s}^{-1}$, at room temperature (two scans)

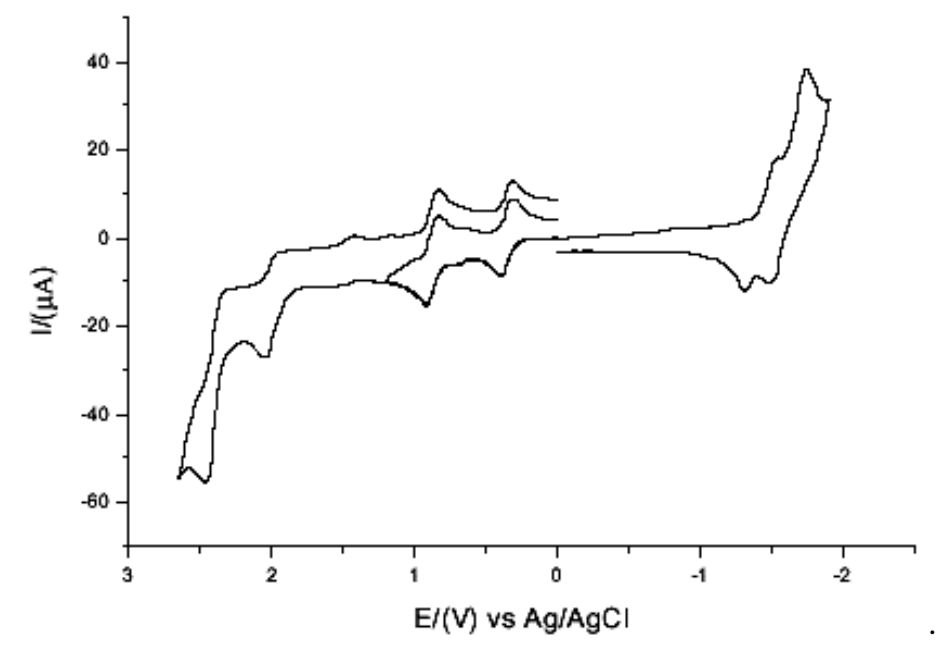

Figure 3. Cyclic voltammetric response for the $\mathrm{A}$ at $200 \mathrm{mV} \mathrm{s}^{-1}$, at room temperature, synthesized form complex cis-[RuCl(bpy) $\left.\left.)_{2}\right)\right] \cdot 2 \mathrm{H}_{2} \mathrm{O}$ and 1, 4-bis(trimethyl-silyl) 1,3-butadiyne (two scans)

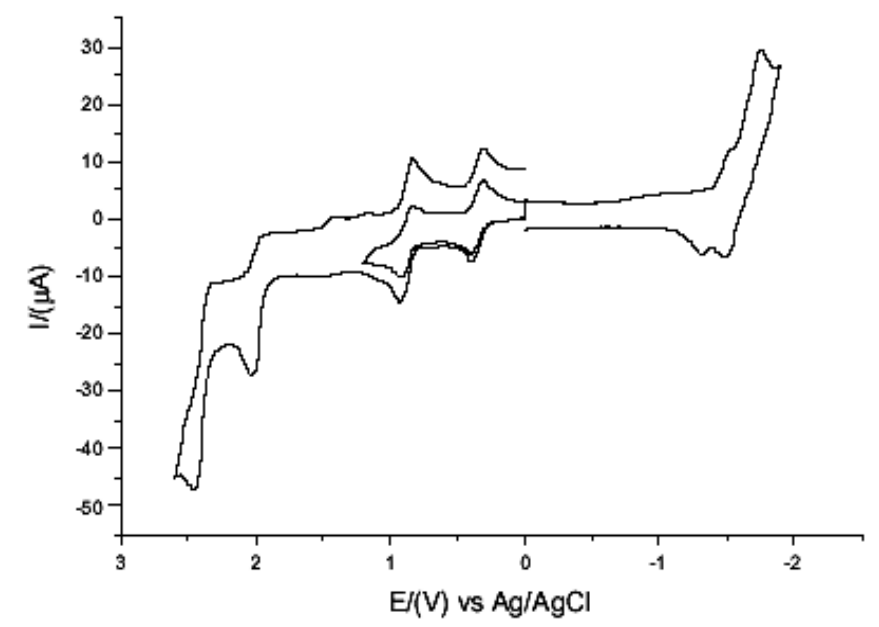

Figure 4. Cyclic voltammetric response for the $\mathrm{A}$ at $200 \mathrm{mV} \mathrm{s}^{-1}$, at room temperature, synthesized form complex cis-[RuCl(bpy) $\left.\left.)_{2}\right)\right] \cdot 2 \mathrm{H}_{2} \mathrm{O}$ and bis(trimethylsilyl)acetylene (two scans). 